\title{
Phytotherapy: an introduction to its history, use and application
}

\author{
FERREIRA, T.S. ${ }^{1}$; MOREIRA, C.Z. ${ }^{1}$; CÁRIA, N. Z..; VICTORIANO, G. ${ }^{2}$; SILVA Jr, W.F. ${ }^{3}$; MAGALHÃES, J.C. ${ }^{3 *}$ \\ ${ }^{1}$ Centro Universitário de Belo Horizonte - UNIBH, Faculdade de Medicina, Av. Prof. Mário Werneck, 1685, CEP: \\ 30455-610, Belo Horizonte - Brasil. ²Universidade Estadual Paulista Júlio de Mesquita Filho, UNESP. Faculdade \\ de Ciências, Av. Eng. Luiz Edmundo Carrijo Coube, 1401, CEP: 17033-360, Bauru - Brasil. ${ }^{3}$ Universidade Federal \\ de São João del Rei, UFSJ. Departamento de Química, Biotecnologia e Engenharia de Bioprocessos, Rodovia \\ MG 443, Km 7 CP: 131, CEP: 36420-000, Ouro Branco - Brasil. *Email: josecarlos@ufsj.edu.br
}

\begin{abstract}
There has been a great advance in the pharmacognosy field, which has increased the use of medicinal plants by health professionals and practitioners of folk medicine. This systematic review explored the history and the present day application of phytotherapeutic medicines. We searched the databases Cochrane Library, Embase, Lilacs, PubMed, Scielo and a specialized bibliography. We concluded that there are many therapeutic potentialities in the use of phytotherapeutic medicines and medicinal plants. We also concluded that despite the increasing number of publications in the field each year, there is still a lack of reviews and meta-analyses that could promote a better integration of the knowledge produced. In addition, research about pharmacological interactions and multidisciplinary studies may promote a quicker and safer process from the workbench up to the clinical trials.
\end{abstract}

Keywords: medicine history, herbal medicine, primitive medicine, phytotherapy.

RESUMO: Fitoterapia: introdução a sua história, uso e aplicação. Diante do avanço que vem ocorrendo na área da farmacognosia, decorrente do aumento do uso de plantas medicinais na medicina popular e por profissionais da saúde, este trabalho apresenta uma revisão sistemática sobre a história dos fitoterápicos e sobre sua aplicação na atualidade. Foram realizadas buscas nas bases de dados Cochrane Library, Embase, Lilacs, PubMed, Scielo e em bibliografia especializada. Concluiu-se que, apesar da quantidade de estudos publicados crescer a cada ano, há ainda escassez de revisões e meta-análises que promovam melhor integração do conhecimento produzido. Pesquisas contemplando interações farmacológicas e trabalhos multidisciplinares podem acelerar os estudos em bases mais seguras, desde a bancada até os ensaios clínicos.

Palavras-chave: história da medicina, ervas medicinais, medicina primitiva, fitoterapia.

\section{INTRODUCTION}

Phytotherapeutics are extracted from medicinal plants and their active ingredients may relieve symptoms and even cure diseases, though they occasionally present adverse effects (TROJANRODRIGUES et al, 2012). It is estimated that $25 \%$ of the Brazilian pharmaceutical industry's earnings are obtained by the sales of plants derivatives, and these revenues continue to grow each year (MINISTÉRIO DE SAÚDE, 2006). In order to control the consumption of these products, many countries created their own regulations. In Brazil, medical, anthropological-social, botanical-economic and economic criteria are taken in consideration by the Plant Selection Committee (MINISTÉRIO DE SAÚDE, 2006). The traditional use of plants for the treatment of diseases by the public and the confirmation of their biological effect have stimulated their therapeutic use. Nevertheless, the advance of research about the components in such plants demonstrates that the use of these plants is beyond its folk medicine use.

This work is a systematic review about Phytotherapy through the Medline/PubMed (Medical Literature Analysis and Retrieval System Online), Embase (Excerpta Medica), Lilacs (Literatura Latino-Americana e Caribe em Ciências da Saúde), Cochrane Library databases and Scielo (Scientific Electronic Library Online) databases. The objective of this work was not to exhaust the subject, considering its extensiveness, but to provide a general introduction to it. There was no restriction to studies in regards to the language or year of publication. 


\section{METHODS}

This work searched for both the history and the present use of phytotherapy. For a historical search of the use of medicine based on plants, specific books relating to this theme were used in addition to published studies. For the description of phytotherapy nowadays in regards to conceptual, epidemiological and regulation data, websites of the Brazilian Ministry of Health (Ministério da Saúde) were also consulted. For the selection of medicinal plants to be pharmacologically described, the adopted criteria were the most frequently researched species in acknowledged pharmacological bibliographies (FUCHS \& WANNMACHER, 2010; KATZUNG, 2007; SILVA, 2010) and phytotherapeutics which have relevant sales volume (TUROLLA, 2006).

In order to enable an evaluation of a great number of found results, the authors stipulated an upper limit of 100 works for each MeSH (Medical Subject Headings) searched, under the criteria presented below (table 1). Starting at the A Level, if the search result presents more than 100 items, it goes on to the next level until the desired number of results is reached. This way, the greater the number of publications, the closer the search strategy will be to level $\mathrm{E}$.

From the obtained results, two authors made the selection independently through abstracts analysis, taking into consideration the study's methodology appropriateness, its comprehensiveness, supportiveness of conclusions and the relevance of the results for our scope of discussion. Disagreements were solved by discussion. Within the selected studies, their preferences were also analyzed and were included in this work when considered relevant by all the authors.

\section{RESULTS}

Tables 2 and 3 represent, respectively, the search results related to the history of the use of medicinal plants and to the medicinal plants pharmacologically described in this work.

According to our findings, humans have used plants as therapeutic tools for many centuries. For some old civilizations, the cure provided by medicinal plants had a magical and supernatural element. Others have believed that these plants acted on the "astral body", producing physiological and paranormal phenomena (ALZUGARAY \& ALZUGARAY, 1996). Medicinal plants had and still have magical-religious meaning for some people (CORDEIRO, 2005; RATES, 2001).

In 1873, the Ebers Papyrus, the most ancient Egyptian medicine treaty - dated 1600 B.C., was found, proving the use of plants for therapeutic purposes (HALLMANN-MIKILAJCAK, 2004). During the Trojan War (1200 a. C), the plant Achillea millefolium was used on wounded soldiers in order to stop bleeding and heal wounds (CÁCERES, 1999). The use of poppy goes back to this period of time as well (CROTEAU et al, 2000).

In Greece, Pedanius Dioscorides (100 B.C.) wrote a treaty about plants called "De Materia Medica", contributing to therapeutic medicine. On the other hand, Socrates and those convicted were executed with poisons extracted from plants (CROTEAU et al, 2000).

In the Middle Ages, Swedish doctor Paracelso was considered the creator of the grounds for natural medicine and for many drugs used nowadays, including opium. In the $18^{\text {th }}$ Century, pharmacognosis ("pharmakon" = drug and "gnosis" $=$ knowledge) was created. It is a multidisciplinary science that acts in the identification and extraction

TABLE 1. Search strategy and its equivalent levels

\begin{tabular}{ll}
\hline Search strategy & Level \\
MeSH & A \\
MeSH [title] & B \\
MeSH [title] and human research & C \\
MeSH [title] and human research and review study & D \\
MeSH [title] and human research and systematic review study & E \\
\hline
\end{tabular}

TABLE 2. Search results for the history of use of medicinal plants and their respective search strategy levels.

\begin{tabular}{llllll}
\hline MeSH & Cochrane Library & Embase & Lilacs & Pubmed & Scielo \\
\hline Primitive medicine & $1 \mathrm{~A}$ & $22 \mathrm{~A}$ & $1 \mathrm{~B}$ & $22 \mathrm{~A}$ & 0 \\
Ancient medicine & $2 \mathrm{~B}$ & $18 \mathrm{~A}$ & $2 \mathrm{~B}$ & $67 \mathrm{~B}$ & $53 \mathrm{~B}$ \\
Phytotherapy & $4 \mathrm{~B}$ & $73 \mathrm{C}$ & $31 \mathrm{~B}$ & $78 \mathrm{D}$ & $52 \mathrm{~B}$ \\
Herbal medicine & $21 \mathrm{~B}$ & $30 \mathrm{E}$ & $20 \mathrm{~B}$ & $58 \mathrm{E}$ & $49 \mathrm{~B}$ \\
\hline
\end{tabular}

Rev. Bras. PI. Med., Campinas, v.16, n.2, p.290-298, 2014. 
of compounds originating in plants and consists of the studies of their physical-chemical, biological activity and pharmaco-toxicological properties (BRUNETON, 1993).

Only in the $19^{\text {th }}$ Century did Botany dissociate from medicine, with phytotherapy being essential at the therapeutic arsenal at the time. In the $20^{\text {th }}$ Century, there was a great development of the industrial processes of manufacturing and synthesis of many medicines, leaving medicinal plants on a secondary plan. However, in 1970, the number of advertisements of new phytotherapeutics in medical magazines increased, proving that such medicines were again an important source of therapeutics (ATTISSO, 1979).

Below, we present an overview of different plants commonly used as herbal medicines. The results were based on searches performed in aforementioned data bases, bibliography and websites of the Brazilian Ministry of Health.

\section{Phytotherapy Nowadays}

Despite the development of the pharmaceutical industry in the post Industrial Revolution period (CORDEIRO, 2005), phytotherapy is still a resource among the therapeutic options (EISENBERG, 1998). In 2006, the Brazilian Ministry of Health made therapeutic and preventive options available to the users of SUS, the Brazilian Health-Care system, among them the use of phytotherapeutics and medicinal plants. The low cost and the cultural compatibility may encourage their use in primary health care, and they may compensate for the chronic lack of medicine in these services. Therefore, the professional qualification of health professionals in the understanding of phytotherapy and its indications is essential (SANTOS, 2011).

In the context of its relevance for public health, studies with Aristolochia cymbifera extracts have revealed action against Leishmania chagasi promastigotes (TEMPONE et al, 2008) and selective action against Trypanossoma cruzi tripomastigotes (SARTORELLI et al, 2010). Other extracts had inhibited the growth of multi-resistant Staphylococcus aureus (ethanolic extract) and bacteria which cause enteric diseases ( $S$. aureus, Bacillus cereus and Klebsiella pneumoniae) (SILVA Jr. et al, 2011).

The Aristolochia paucinervis species has an antimicrobial activity, inhibiting the growth of Clostridium perfringens, Clostridium difficile, Enterococcus faecalis, Micrococcus lutens and Bacillus subtilis (TIAN-SHUNG et al, 2004). However, such plant species possess compounds called aristolochic acids, which have been related to nephropathy and carcinogenesis (CAl et al, 2010; CHEN et al, 2010).

Other plants, such as Myrospermum erythroxylon, inhibit the growth of many Staphylococcus aureus strains, including multiresistant ones, and also show activity against Pseudomonas aeruginosa (MACHADO et al, 2005). Bathysa cuspidata, Cosmos sulphureus, Cecropia hololeuca, Erisma calcaratum, Gomphrena arborescens, Musa paradisiaca, Ocotea odorifera, and Pradosia lactescens are reported as potential malaria treatment (BOTSARIS, 2007). According to RATES (2001), there is a basic misunderstanding by users who previously considered phytotherapeutic medicines to be safe, simply because they are from natural sources (EISENBERG, 1998; RATES, 2001). The same occurs with medicinal plants. Medicinal plants are those used in prophylaxis, relief and cure, generally used in folk medicine such as teas or infusions. Phytotherapeutics, however, are finished and labeled products, whose active ingredients come from plants, in a raw state or in plant preparations (RATES, 2001). That is, they are medicines validated by their efficacy and whose plant composition is known and production is supervised.

TABLE 3. Search results for the medicinal plants and their respective strategy levels.

\begin{tabular}{llllll}
\hline MeSH & Cochrane Library & Embase & Lilacs & Pubmed & Scielo \\
\hline Aesculus hippocastanum & 0 & $18 \mathrm{C}$ & $3 \mathrm{~A}$ & $72 \mathrm{~B}$ & $1 \mathrm{~B}$ \\
Cimicifuga racemosa & 0 & $86 \mathrm{C}$ & $10 \mathrm{~A}$ & $62 \mathrm{C}$ & $1 \mathrm{~B}$ \\
Ginkgo biloba & $6 \mathrm{D}$ & $38 \mathrm{D}$ & $58 \mathrm{~A}$ & $89 \mathrm{D}$ & $10 \mathrm{~B}$ \\
Hypericum perforatum & 1 D & $38 \mathrm{D}$ & $28 \mathrm{~A}$ & $36 \mathrm{D}$ & $9 \mathrm{~B}$ \\
Panax ginseng & $2 \mathrm{D}$ & $53 \mathrm{D}$ & $15 \mathrm{~A}$ & $17 \mathrm{D}$ & 0 \\
Passiflora incarnata & 0 & $21 \mathrm{~B}$ & $15 \mathrm{~A}$ & $79 \mathrm{~A}$ & $2 \mathrm{~B}$ \\
Piper methysticum & $1 \mathrm{D}$ & $45 \mathrm{~B}$ & $9 \mathrm{~A}$ & $80 \mathrm{~B}$ & $2 \mathrm{~B}$ \\
Plantago ovata & 0 & $56 \mathrm{~B}$ & $2 \mathrm{~A}$ & $81 \mathrm{~A}$ & $1 \mathrm{~B}$ \\
Rhamnus purshiana & 0 & $2 \mathrm{~A}$ & $1 \mathrm{~A}$ & $17 \mathrm{~A}$ & 0 \\
Valeriana officinalis & 0 & $52 \mathrm{~A}$ & $20 \mathrm{~A}$ & $81 \mathrm{~B}$ & $8 \mathrm{~A}$ \\
\hline
\end{tabular}

Rev. Bras. Pl. Med., Campinas, v.16, n.2, p.290-298, 2014. 
Plant preparations which have isolated active ingredients are not considered phytotherapeutic medicine (ANVISA, 2012).

KINGHORN (2001) has attributed the phenomenon of the increase of the use of phytotherapy and its considerable impact on the economy to some dissatisfaction with allopathic medicine, ecological awareness, and a lack of access to synthetic drugs.

Important medications such as atropine, scopolamine, morphine, codeine, digoxin and curare are extracted from plants (RATES, 2001). These plants are consumed in natura as teas or other homemade preparations, and they are intended for domestic or ritualistic uses, or still as paints, powders, pills, capsules, extracts, etc. As they undergo processes of extraction, separation and purification, the bioactive substances (i.e. Quinine, digoxin, ergotamine) from the plants can be isolated. Such compounds are called phytomedicine (VEIGA Jr. et al, 2005).

It is important to mention that "medicinal plants" are neither phytomedicines, nor phytotherapeutics. The latter, once classified as a medicine, is subject to the ethical standards defined by World Health Organization (WHO), and goes through careful production processes from the time of collection and formulation until the time of packaging and distribution. Just like any medicine, phytotherapeutics in Brazil must pass validation tests of pharmacological effects, toxicological analysis and be registered at ANVISA (CARVALHO et al, 2007). Even though there are still discrepancies between the definitions of phytotherapeutics and medicinal plants, these terms are often used as synonyms. Therefore, it can be said that phytotherapeutic medicines are composed of medicinal plants (almost completely), but not every medicinal plant can be considered phytotherapeutic.

\section{Popular use of phytotherapeutics and its implications}

World Health Organization (WHO) has been promoting the use of alternative therapies integrated with technical knowledge of Western Medicine since 1976 (ALVES \& SILVA, 2003). According to $\mathrm{WHO}$, about $85 \%$ of the world population uses phytotherapeutic medicines for therapeutic purposes (OLIVEIRA et al, 2006). Since the 80s, Brazilian studies have tried to quantify the use of medicinal plants and phytotherapeutics by the population, especially among pregnant women and mothers of children up to age 5 , discovering that the culture of its use was passed from generation to generation. Alternative methods have been used more, because of the lack of credibility in allopathic medicine and the low cost of phytotherapy (ALVES, 2003). The growing use of medicinal plants by the population is due to low cost and easy access (SANTOS, 2011).

Despite the disseminated use of medicinal plants for many functions, it is of utmost importance to show that many adverse side effects, some very severe, were attributed to some species (ERNST, 1999). Some side effects such as allergic reactions, mutations, intoxication, teratogenesis, carcinogenesis and medication interactions may occur if the use of the phytotherapeutic or medicinal plant is unrestricted. The lack of a stricter control of these medicines enables contamination by heavy metals, conventional drugs, herbicides or pesticides, (ERNST, 1999; ALMEIDA et al, 2005).

\section{Pharmacological characteristics of some of the main medicinal plants described in the literature}

\section{Aesculus hippocastanum}

Native of the Balcans, Aesculus hippocastanum is cultivated worldwide (MARTINS \& BRANDÃO, 2006). It is a complex mix of saponins, especially $\beta$-escin, tannins, D-catechol, pectin, potassium, volatile oil, calcium, phosphorus, bioflavonoids and A2 proanthocyanidins (AESCULUS, 2009). Its mechanism of action favors the transportation of ions through the calcium canals and reduces the activation of leukocytes (AESCULUS, 2009). It is clinically recommended in cases of chronic venous insufficiency, varicose veins, hemorrhoids, low perfusion of the inner ear and postoperative edema (DICKSON et al, 2004). It causes an increase in the antioxidant defense system of the organism and it acts as an anti-inflammatory. When associated with an anticoagulant medicine, it may increase its effect (AESCULUS, 2009).

In recommended dosage, there are few side effects. However, the manifestation of gastrointestinal symptoms, dizziness, headaches and itching is common. The standard dosage takes $16-20 \%$ of escin. The prescribed oral dosage is $100-150 \mathrm{mg} /$ day and the topical use is $2 \%$ of escin, three to four times a day (AESCULUS, 2009).

\section{Cimicifuga racemosa}

Native of the temperate zones in North America, Cimicifuga racemosa is known in these regions as "Black Cohosh", but called "Erva-de-SãoCristóvão" in Brazil. Its extract contains triterpenic glycosides, alkaloids, and aromatic acids. The nature of the extract modifies its activity (LOPES, 2008). Its mechanism of action involves the reduction of serum levels of luteinizing hormone (LH) through negative feedback in estrogen receptors. It has partial agonist action in opioids receptors and hypotensive action in central vasomotor centers 
(RHYU, 2006). It is recommended for amenorrhea, dysmenorrhea and difficulties to normalize the rhythmic activity of the uterus postpartum, eczemas, edemas, asthma, migraine, inflammations, metabolic disorders, muscular rheumatism and rheumatoid arthritis (LOPES, 2008). It antagonizes the immunosuppressive effect of cyclosporine, causing rejection in transplant patients. It is also compatible with oral contraceptives and hormones as conjugated estrogen (NICOLETTI, 2010) and it may cause side effects such as digestive discomfort attributed to glycosides, head ache, nausea, vomit, visual alterations, tremors, nervous unsettlement, abdominal pain, and possible hepatic injury. The recommended daily dosage of the extract is $40 \mathrm{mg}$. The first therapeutic effects are noticed after two weeks of treatment (RACEMOSA, 2003).

\section{Ginkgo biloba}

It originated in Korea, China and Japan and it is used worldwide. It is constituted by $24 \%$ of ginkgo flavone glycosides and $6 \%$ of terpenoids (FORLENZA, 2003). Ginkgo biloba has antioxidant mechanism of action (MACARENCO et al, 2001) and antiapoptotic activity (FORLENZA, 2003). It reduces clastogenic activity, has an anti-ischemic effect and causes vascular relaxation via nitrous oxide. G. biloba possibly potentiates the effect of acetylcholinesterase (CZAP, 2002). Therefore, it is recommended for clinical treatment of Alzheimer's disease (FORLENZA, 2003), cardiovascular diseases, sexual impotence, hepatic fibrosis, memory improvement, cerebral vascular insufficiency, PMS and some kinds of cancer (CZAP, 2002). In patients administered with anticoagulants, there may be a formation of subdural hematoma (ROSENBLATT \& MINDEL, 1997). Some side effects may be observed, such as nausea, vomit, salivation, loss of appetite, headaches, vertigo, ringing in the ears and hypersensitivity reaction, such as a cutaneous rash. The mutagenic effect of $G$. biloba was not documented. The recommended dosage is $40-80 \mathrm{mg}$ of the plant extract, two or three times a day (CZAP, 2002). For Alzheimer's patients, 240 mg should be administered daily.

\section{Hypericum perforatum}

This plant is known as "Saint John's wort" or "Erva-de-São-João". Hipericum perforatum is found in America, Europe, and Asia. From its flowers, it is possible to extract a red substance which contains hypericins (HYPERICUM, 2004). It is comprised of tannins, resins, pectin, naftodiantrona, and flavonoids with anti-inflammatory and antiviral properties (luteolin, kaempferol, isoquercetine, quercetine, rutine, myricetin) (YUNES et al, 2001). Also, it contains procianydins, phytosterols, vitamin
C, carotene, aminoacids and saponins (GREESON et al, 2001). The composition of these substances varies according to the shape, time and place of cultivation (KARIOTI \& BILIA, 2010). It is believed that there are components in this plant that can inhibit the absorption of serotonin, noradrenalin and dopamine (HYPERICUM, 2004) given that some studies suggest that hypericin and pseudohypericin are partially responsible for the antidepressant effect. Others attribute this effect to hyperforins. The plant extract is used in the treatment of light to moderate depression, with the antidepressant used more in Europe, the leader in prescriptions and consumption (CORDEIRO, 2005). Among the mechanisms of action mentioned are the interaction with the $y$-aminobutyric acid (GABA) receptors and the inhibition of the monoamine oxidase enzymes and catecol-o-metiltransferase (YUNES et al, 2001). There is evidence of the reduction of serum concentrations of protease inhibitors, simvastatin, tricyclic antidepressants, carbamazepine, phenytoin, phenobarbital through cytochrome P450 and isoenzyme CYP1A2. The hypericum may cause mainly photosensitivity on the skin and in the eyes, and it proved to be dosage-dependent. The used dosage varies from 500 to $1,050 \mathrm{mg}$ for the treatment of light or moderate depressions, taken two or three times a day (HYPERICUM, 2004). Studies still document its antiviral activity against simplex herpes virus type 1 , murine cytomegalovirus, and human immunodeficiency virus type 1, among other enveloped viruses (YUNES et al, 2001).

\section{Panax ginseng}

Panax ginseng originated in East Asia and Russia (SEELY et al, 2008). Its root is the most commonly used structure in medicine. It is constituted by: saponins, amino acids, alkaloids, phenols, proteins, polypeptides and vitamins B1 and B2. These substances help with biochemical resistance and stress agents, inducing an increase in vitality, longevity and mental capacity (PANAX, 2009). This plant is used in the clinical treatment of anxiety (HEAD \& KELLY, 2009; SAEED et al, 2007). Studies affirm that $P$. ginseng strongly inhibits cytochrome P450 (SINGH \& SINGH, 2002; SINGH, 2005). Its extended use may cause a reversible rash and slight jaundice (PIPER, 1998; SAEED et al, 2007). The recommended dosage is 50 to $70 \mathrm{mg}$, three times a day, in order to achieve the therapeutic range (PIPER, 1998). There was no evidence of interactions between $P$. ginseng and other drugs or teratogenic and hormonal effects (SEELY, 2008) in pregnant or lactating women. Its toxicity is low and dosage-dependent. Few adverse effects were reported, including hypertension, nausea, diarrhea, headaches, insomnia, and rash. For therapeutic 
dosage, raw solid preparations of 1-2 g should be ingested daily for three months. The liquid formula with $1: 2$ concentration should be dosed at 1-6 $\mathrm{ml}$ per day (PANAX, 2009).

\section{Passiflora incarnata}

It is a native plant of the U.S.A., known as passion fruit, whose aerial parts are usually used. It is comprised of flavonoids, alkaloids, and other constituents less discussed in literature, such as pectin (PEREIRA \& VILEGAS, 2000). Its action depresses the central nervous system, possibly in benzodiazepine sites. It was attested that the use of flumazenil, an antagonist of the benzodiazepine receptor, blocked the effect of the phytotherapeutic (NASSIRI-ASL, 2007). There were stages of irritability and nervous agitation, insomnia and anxiety disorders (TABACH et al 2009) during its use. There are still studies about its effectiveness as an anticonvulsant, aphrodisiac, antitussive, sexual dysfunction, and cancer (PATEL et al, 2008). Passiflora incarnata potentiates the effects of pentobarbital, hexobarbital and amino oxidase inhibitors. There may be a possible interaction with warfarin (BRINKER, 2001; NEWALL, 1996).

There are few reports of toxicity with the use of $P$. incarnata, but there has been nausea, vomit, ventricular arrhythmia and prolonged sedation. The therapeutic dosage of $P$. incarnata is $500-1000 \mathrm{mg}$, three times a day (MOVAFEGH et al, 2008).

\section{Piper methysticum}

Known as kava kava, (CORDEIRO, 2005), Piper methysticum originated in the Pacific Islands (SHULGIN, 1973). For centuries, natives prepared a mixture of the plant's extract with water or coconut milk (PIPER, 1998). It is made of lactones, kavalactones or kavapirones, which work as the active ingredient of the phytotherapeutic (CLAUDINO et al, 2001; PIPER, 1998; SHULGIN, 1973). The lactones connect and potentiate the activity of the GABA receptors (PIPER, 1998; SAEED et al, 2007), and also inhibit the reuptake of noradrenaline or block serotonin secretion (PIPER, 1998; SEITZ et al, 1997).

\section{Rhamnus purshiana}

The most common commercial names of Rhamnus purshiana are: Eparema (Altana Pharma) and Cáscara Sagrada (Herbarium) (NADIR et al, 2000). Its constituent substances are cascarosides $A, B, C$ and $D$, tannin, saponin, aloin and free antraquinones (BLUMENTHAL et al, 1998). Its action involves the stimulation of nervous terminations of the intestinal mucus, increasing peristalsis and stool humidity. The inhibition of sodium and potassium canals, increasing the flow of liquid to the extracellular environment, may also occur (BLUMENTHAL et al, 1998). R. purshiana is clinically recommended in cases of occasional constipation. There is evidence of the potentiation of the effects of thiazide diuretics and corticoadrenal steroids, in addition to the reduction of the effects of antiarrhythmics (NADIR et al, 2000). Some side effects are: arrhythmia, hypokalemia and nephropathy. Its extended use may lead to the destruction of the colon's nervous plexus, which causes cramps, irritation of the digestive mucosa and reduction of the intestinal mobility (WILLEMS et al, 2003). The recommended oral dosage should be at the doctor's discretion. The treatment should not be continuous and it should not last more than ten consecutive days (BLUMENTHAL et al, 1998).

\section{Valeriana officinalis}

With its use described by Hypocrates, Valeriana officinalis is native to Europe and north of Asia (WICHTL, 1994). It presents a characteristic odor and it has rhizome, roots and stem used in the manipulation of many preparations (BLUMENTHAL, 1998). It has multiple constituents such as valerianic acid, sesquiterpenes and valepotriates. No study was able to show the effectiveness of these constituents separately (HENDRIKS et al, 1981). Its effect favors the increase of the GABA synthesis in the synaptic gap (SANTOS et al, 1994) and inhibits its destruction (MORAZZONI et al, 1995). The presence of glutamine in some preparations may help its effects (CAVADAS et al, 1995). V. officinalis is clinically recommended in cases of sleep disorders and light insomnia (POYARES et al, 2005) and may have an addictive effect in people who use alcohol or other sedatives (ROTBLATT et al, 2002). There were not strict studies related to the interactions of the phytotherapeutic with other drugs (DAVIDSON et al, 2000). It has counter indications such as headache, dizziness, itching and gastrointestinal disorders. However, there is no report of toxicity of the medication, even though some data indicate that it may be related to the dosage (DONATH et al, 2000). The used dosage is $400-900 \mathrm{mg}$ of its extract for 28 days it is a combination of $187 \mathrm{mg}$ of valerian extract with $41.9 \mathrm{mg}$ of humulus lupulus extract per tablet, 2 tablets at sleep time for 28 days (PLUSHNER, 2000).

\section{Plantago ovata}

Plantago ovata is cultivated in Iran, Pakistan, and especially India. Its seeds have mucilage as its main constituent. It is rich in polysaccharides with a slight acidic character and fibers (SOUSA, 2008). The mechanism of action of the plant involves the reduction of cholesterol absorption by the intestine and the increase of its excretion and gallbladder acid. 
The absorption of carbohydrates by the intestine may also be reduced (PLANTAGO, 2002). P. ovata is indicated for clinical cases of chronic intestinal constipation, fecal incontinence, hemorrhoids, hypercholesterolemia and diabetes (NICOLETTI, 2010). The seeds are used by the pharmaceutical industry in the treatments of intestinal cancer and amoebic dysentery (SOUSA, 2008). This plant also interferes in the intestinal absorption of minerals and vitamins (especially B12) and it is not recommended to be consumed with antidiarrheal treatments and intestinal motility inhibitors, as the intestine can be obstructed (NICOLETTI, 2010). Rarely are there side effects if the recommended dosage is administrated correctly. In cases of overdose, intestinal cramps and severe diarrhea with loss of liquid and electrolytes may occur. The recommended dosage is 10 to 30 $\mathrm{g}$ a day, divided in two doses. It is recommended to start with a lower dosage and gradually increase it whenever necessary (PLANTAGO, 2002).

\section{DISCUSSION E CONCLUSION}

In addition to what has already been discussed in this work, there is still much to be discussed about the use and application of herbal medicines, which has many open questions and inconclusive studies. The number of researches in the field has increased every year. Many studies relate to specific phytotherapeutics but few present a broad range of background information that comprehensively discusses the topic. There are fewer reviews or meta-analyses than those typically seen in other fields such as cancer research, stem cells, hypertension and HIV.

Currently, there is great potential for new drug development produced either directly from biologically active natural products, or synthetically, based on their chemical structure. A considerable number of articles relate to drug toxicity and safety, emphasizing that such drugs may indeed have adverse effects. An overview of systematic reviews about the adverse effects of herbal medicines found serious adverse effects for Piper methysticum, moderately severe adverse effects for Cimifuga racemosa and minor adverse effects for Panax ginseng, Hypericum perforatum, Gingko biloba, Valeriana officinalis and Aesculus hippocastanum (POSADZKI et al, 2013).

Many authors have promoted elegant experiments using isolated compounds from plant species; additionally there are numerous studies using raw plant extracts. These papers define the actual active agents and the synergistic effects of multiple extracts in some cases which differ according to locations and traditions.

Taking into consideration the biologic diversity especially in countries like Brazil and the many undiscovered biologics and their medicinal potential, there is still much to be investigated. Also, efforts to integrate the knowledge gleaned from drug interactions and the results of multidisciplinary research teams will accelerate the advances in translational science from in vitro studies to clinical trials, providing safer and more effective benefits to society.

\section{REFERENCE}

AESCULUS hippocastanum (Horse chestnut). Alternative Medicine Review, v.14, n.3, p.278-83, 2009.

ALMEIDA, A.A.; MING, T.D.; CORREAA, C.L.; LAVINAS, T. Verificação da qualidade dos fitoterápicos sene e boldo-do-chile comercializados na região de Campinas. Revista de Ciências Médicas, v.14, n.3, p.279-85, 2005.

ALVES, A.R.; SILVA, M.P. O uso da fitoterapia no cuidado de crianças com até cinco anos em área central e periférica da cidade de São Paulo. Revista da Escola de Enfermagem da USP, v.37, n.4, p.85-91, 2003.

ALZUGARAY, D.; ALZUGARAY, C. Plantas que curam. v.1. São Paulo: Três; 1996. 260p.

ANVISA. Medicamentos fitoterápicos. Disponível em: < http://portal.anvisa.gov.br/wps/content/Anvisa+Portal/ Anvisa/Inicio/Medicamentos/Assunto+de+Interesse/ Medicamentos+fitoterapicos>. Acesso em: 17 jul. 2012.

ATTISSO, M.A. As plantas medicinais voltam a florescer. O correio da UNESCO, v.7, n.9, p.6-8, 1979.

BARROS MACHADO, T. et al. Brazilian phytopharmaceuticals--evaluation against hospital bacteria. Phytotherapy Research, v.19, n.6, p.51925, 2005.

BLUMENTHAL, M. et al. The complete commission $\mathbf{E}$ monographs: therapeutic guide to herbal medicines. 1ed. Boston: M. Integrative medicine communications. p.104-105.1998.

BOTSARIS, A.S. Plants used traditionally to treat malaria in Brazil: the archives of Flora Medicinal. Journal of Ethnobiology and Ethnomedicine, v.3, p.18, 2007.

BRANDÃO, G.C. et al. Antiviral activity of Bigoniaceae species occurring in the State of Minas Gerais (Brazil): part 1. Letters in Applied Microbiology, v.51, p.469476, 2010.

BRINKER, F. Herb Contraindications and Drug Interactions. 3.ed. Oregon: ND Eclectic Medical Publications, 2001. 440p.

BRUNETON, J. Pharmacognosie, phytochimie, plantes médicinales. 2.ed. Paris: Lavoisier; 1993. 915p.

BRUNTON, L.L.; CHABNER, B.; KNOLLMANN, B.C. (Org.). As bases farmacológicas da terapêutica de Goodman \& Gillman. 12.ed. Rio de Janeiro: McGrawHill, 2012. 2112p.

CÁCERES, A. Plantas de Uso Medicinal em Guatemala. 2.ed. Guatemala: Editorial Universitária, 1999. 402p.

CAI Y, CAI T. Two New Aristolochic Acid Derivatives from the Roots of Aristolochia fangchi and Their Cytotoxicities. Chemical and Pharmaceutical Bulletin, v. 58 , n. 8, p. 1093-1095, 2919. Chem. Pharm. Bull. 2010; 58(8): 1093-1095.. 
CARVALHO; A.C.B.et al. Aspectos da legislação no controle dos medica mentos fitoterápicos. T\&C Amazônia, v. 5, n. 11, p.26-32, 2007.

CAVADAS, C. et al. In vitro study on the interaction of Valeriana officinalis $L$. extracts and their amino acids on GABAA receptor in rat brain. Arzneimittel-Forschung Drug Research, v.45, n.7, p.753-55, 1995.

CHEN, Y. et al. Aristolochic acid suppresses DNA repair and triggers oxidative DNA damage in human kidney proximal tubular cells. Oncology Reports, v.24, n.1, p.141-153, 2010.

CLAUDINO, T.S. et al. Aplicação da síntese orgânica em fase sólida (SOFS) para a funcionalização do éster acetoacético. Caderno de Farmácia, v.17, n.2, p. 121-25, 2001.

CORDEIRO, C.H.G. et al. Interações medicamentosas de fitoterápicos e fármacos: Hypericum perforatum e Piper methysticum. Revista Brasileira de Farmacognosia, v.15, n.3, p.272-78, 2005.

CROTEAU, R. et al. Natural products (secondary metabolites). In: Biochemistry \& molecular biology of plants. Rockville: Courier Companies, 2000. p.12501318.

CZAP, K. Ginkgo biloba. Alternative Medicine Review Monographs, Thorne Research Inc. p.168-174, 2002.

DAVIDSON, J.R.T.; CONNOR, K.M. Herbs for the Mind: Depression, Stress, Memory Loss, and Insomnia. New York: Guilford Press, 2000. p.214-233.

DICKSON, S. et al. An open study to assess the safety and efficacy of Aesculus hippocastanum tablets (Aesculaforce $50 \mathrm{mg}$ ) in the treatment of chronic venous insufficiency. Journal of Herbal Pharmacotherapy, v.4, n.2, p.19-32, 2004.

DONATH, F. et al. Critical evaluation of the effect of valerian extract on sleep structure and sleep quality. Pharmacopsychiatry, v.33, n.2, p.47-53, 2000.

EISENBERG, D.M. et al. Trends in alternative medicine use in the United States, 1990-1997 results of a followup national survey. JAMA, v.280, n.18, p.1569-75, 1998.

ERNST, E. Adverse reactions to herbal treatments. Journal of the Royal Society of Medicine, v.92, n.7, p.386, 1999.

FORLENZA, O.V. Ginkgo biloba e memória: mito ou realidade?. Revista de Psiquiatria Clínica, v.30, n.6, p.218-20, 2003

FUCHS, F.D.; WANNMACHER, L. Farmacologia clínica: fundamentos da terapêutica racional. 4. ed. Rio de Janeiro: Guanabara Koogan, 2010. 1096p.

GREESON, J.M. etal. St. John'swort (Hypericumperforatum): a review of the current pharmacological, toxicological, and clinical literature. Psychopharmacology, v.153, n.4, p.402-14, 2001.

HALLMAN-MIKOLACZAK. A. Ebers Papyrus. The book of medical knowledge of the 16th century B.C. Egyptians. Archiwum historii i filozofii medycyny / Polskii Towarzystwo Historii Medycyny i Farmacji, v.67, n.1, p.5-14, 2004.

HAMMER, K.A. et al. Antifungal effects of Melaleuca alternifolia (tea tree) oil and its components on Candida albicans, Candida glabrata and Saccharomyces cerevisiae. Journal of Antimicrobial Chemotherapy, v.53, n.6, p.1081-1085, 2004.

HEAD, K.A.; KELLY, G.S. Nutrients and Botanicals for
Treatment of Stress: Adrenal Fatigue, Neurotransmitter Imbalance, Anxiety, and Restless Sleep. Alternative Medicine Review, v.14, n.2, p.114-40, 2009.

HENDRIKS, $\mathrm{H}$. et al. Pharmacological screening of valerenal and some other components of essential oil of Valeriana officinalis. Planta Medica, v.42, n.50, p.62-68, 1981.

HYPERICUM perforatum. Alternative Medicine Review, v.9, n.3, p.318-25, 2004.

JASSIM, S.A.A.; NAJI, M.A. Novel antiviral agents: a medicinal plant perspective. Journal of Applied Microbiology, v.95, n.3, p.412-427, 2003.

KARIOTI, A.; BILIA, A.R. Hypericins as Potential Leads for New Therapeutics. International Journal of Molecular Sciences, v.11, n.2, p.562-94, 2010.

KATZUNG, B.G. (Coord.). Farmacologia: básica e clínica. 10.ed. São Paulo: McGraw-Hill, 2007. 1088p.

KINGHORN, A.D. Pharmacognosy in the 21st century. Journal of Pharmacy and Pharmacology, v.53, n.2, p.135-148, 2001.

LOPES, C.M.C.et al. função hepática em mulheres menopausadas tratadas com extrato seco padronizado do rizoma e raízes de Cimicifuga racemosa L. Revista Brasileira de Medicina, v.66, n.8, p.254-259, 2009.

MACARENCO, R.S.S. et al. Estudo da ação do extrato de Ginkgo biloba e amido hidroxietílico hipertônico na atenuação de alterações decorrentes de isquemia e reperfusão de órgãos esplâncnicos em ratos. Acta Cirurgica Brasileira, v.16, n.3, p.139-145, 2001.

MARQUES, L.C.; PETROVICK, P.R. Normatização da produção e comercialização de fitoterápicos no Brasil. In: Farmacognosia: da planta ao medicamento. 5.ed. Florianópolis e Porto Alegre: UFSC e UFRGS, 2003. p.261299.

MARTINS, E.L.P.; BRANDÃO, M.G. Qualidade de amostras comerciais preparadas com Aesculus hippocastanum L. (castanha-da-Índia). Revista Brasileira de Farmacognosia, v.16, n.2, p.224-229, 2006.

MELO, M.M. et al. Plant extracts for topic therapy of Bothrops alternatus envenomation. Revista Brasileira de Farmacognosia, v.17, n.1, p.29-34, 2007.

MINISTÉRIO DA SAÚDE. A Fitoterapia no SUS e o Programa de Pesquisas de Plantas Medicinais da Central de Medicamentos. 1.ed. Brasília: MS, 2006. $148 p$.

MORAZZONI, P.; BOMBARDELLI. E. Valeriana officinalis: traditional use and recent evaluation of activity. Fitoterapia, v.66, n.2, p.99-112, 1995.

MOVAFEGH et al. Preoperative Oral Passiflora Incarnata Reduces Anxiety in Ambulatory Surgery Patients: A Double-Blind, Placebo-Controlled Study. Anesthesia \& analgesia, v.106, n.6, p.1728-1732, 2008.

MURRIA, R.D.H. et al. Diterpeno com atividade antiLeishmania isolado de folhas de Aristolochia cymbifera (Aristolochiaceae). In: $31^{\text {a }}$ Reunião Anual da SBQ, 31., 2008, Brasil. Proceedings... Brasil.

NADIR, A.; REDDY, D.; VAN-THIEL, D.H. Cascara sagrada-induced intrahepatic cholestasis causing portal hypertension: case report and review of herbal hepatotoxicity. American Journal of Gastroenterology, v.95, n.12, p.3634-3637, 2000.

NASSIRI-ASL, M. ET AL. Anticonvulsant effects of

Rev. Bras. PI. Med., Campinas, v.16, n.2, p.290-298, 2014. 
aerial parts of Passiflora incarnate extract in mice: involvement of benzodiazepine and opioid receptors. BMC Complementary and Alternative Medicine, v.7, p.26, 2007.

NEWALL, C.A. et al. Herbal Medicines: A Guide for Health-Care Professionals.2.ed. Londres: The Pharmaceutical Press, 1996. 432p.

NICOLETTI, M.A. et al. Uso popular de medicamentos contendo drogas de origem vegetal e/ou plantas medicinais: principais interações decorrentes. Revista Saúde, v.4, n.1, p.25-39, 2010.

OLIVEIRA, M.J.R. et al. Fitoterapia no Sistema de Saúde Pública (SUS) no Estado de São Paulo, Brasil. Revista Brasileira de Plantas Medicinais, v.8, n.2, p.39-41, 2006.

PANAX ginseng. Alternative Medicine Review, v.14, n.2, p.172-176, 2009.

PATEL, S.S. et al. Passiflora incarnata Linn: a phytopharmacological review. International Journal of Green Pharmacy, v.3, n.4, p.277-280, 2009.

PIPER methysticum (kava kava). Alternative Medicine Review, v.3, n.6, p.458-460, 1998.

PLANTAGO ovata (Psyllium). Alternative Medicine Review, v.7, n.2, p.155-159, 2002.

PLUSHNER, S.L. Valerian: Valeriana officinalis. American Journal of Health-System Pharmacy, v.57, n.4, p.328335, 2000.

POYARES, D. et al. Hipnoindutores e insônia. Revista Brasileira de Psiquiatria, v.27, n.1, p.2-7, 2005.

POSADSKI, P. et al. Adverse effects of herbal medicines: na overview of systemic reviews. Clinical Medicine, v.13, n.1, p.7-12, 2013.

RACEMOSA cimicifuga. Alternative Medicine Review, v.8, n.2, p.186-189, 2003

RATES, S.M.K. Promoção do uso racional de fitoterápicos: uma abordagem no ensino de Farmacognosia. Revista Brasileira de Farmacognosia, v.11, n.2, p.57-69, 2001.

RHYU, M-R. et al. Black cohosh (Actaea racemosa, Cimicifuga racemosa) behaves as a mixed competitive ligand and partial agonist at the human $\mu$ opiate receptor. Journal of Agricultural and Food Chemistry, v.54, n.26, p.9852-9857, 2006.

ROSENBLATT, M.; MINDEL, J. Spontaneous Hyphema Associated with Ingestion of Ginkgo biloba Extract. The New England Journal of Medicine, v.336, n.15, p.1108, 1997.

ROTBLATT, M.; ZIMENT, I. Valerian (Valeriana officinalis). In: Evidence-Based Herbal Medicine. Philadelphia: Hanley \& Belfus, Inc. 2002. p.355-359.

SAEED, S.A. et al. Herbal and Dietary Supplements for Treatment of Anxiety Disorders. American Family Physician, v.76, n.4, p.549-556, 2007.

SANTOS, M.S. et al. An aqueous extract of valerian influences the transport of GABA in synaptosomes. Planta Medica, v.60, n.3, p.278-279, 1994.

SARTORELLI, P. et al. Antitrypanosomal Activity of a Diterpene and Lignans Isolated from Aristolochia cymbifera. Planta Medica, v.76, n.13, p.1454-1456, 2010.
SEELY, D. et al. Safety and efficacy of Panax ginseng during pregnancy and lactation. Canadian Journal of Clinical Pharmacology, v.15, n.1, p.87-94, 2008.

SEITZ, U. et al. [3H]-monoamine uptake inhibition properties of kava pyrones. Planta Medica, v.63, n.6, p.548-549, 1998.

SILVA Jr, W.F. et al. Análise da atividade antimicrobiana e da citotoxicidade em extratos diclorometânico, hidro alcoólico e hexânico de Aristolochia cymbifera. 2011. 44p. Trabalho de conclusão de curso (Graduação em Engenharia de Bioprocessos) - Departamento de Química, Biotecnologia e Engenharia de Bioprocessos, Universidade Federal de São João del Rei, Minas Gerais.

SILVA, P. Farmacologia. 8.ed. Rio de Janeiro: Guanabara Koogan, 2010. 1352p.

SINGH, Y.N. Potential for interaction of kava and St. John's wort with drugs. Journal of Ethnopharmacology, v.100, n.2, p.108-113, 2005.

SINGH, Y.N.; SINGH, N.N. Therapeutic potential of kava in the treatment of anxiety disorders. CNS Drugs, v.16, n.13, p.731-743, 2002.

SOUSA, M. P. et al. Germinação de sementes de Plantago ovata Forsk. (Plantaginaceae): temperatura e fotoblastismo. Revista Árvore, v.32, n.1, p.51-57, 2008.

TABACH, R. et al. Pharmacological evaluation of a phytotherapeutic product - CPV (dry extract of Crataegus oxyacantha L., Passiflora incarnata L. and Valeriana officinalis $L$. in laboratory animals. Revista Brasileira de Farmacognosia, v.19, n.1B, p.255260, 2009.

TEMPONE, A.G. et al. Brazilian flora extracts as source of novel antileishmanial and antifungal compounds. Memórias do Instituto Oswaldo Cruz, v.103, n.5, p.443-449, 2008. 443-449.

TIAN-SHUNG, W. et al. Terpenoids of Aristolochia and their biological activities. Natural Product Reports, v.21, n.5, p.594-624, 2004.

TROJAN-RODRIGUES, M. et al. Plants used as antidiabetics in popular medicine in Rio Grande do Sul, southern Brazil. Journal of Ethnopharmacology, v.139, p.155-163, 2012.

TUROLLA, M.S.R.; NASCIMENTO, E.S. Informações toxicológicas de alguns fitoterápicos utilizados no Brasil. Revista Brasileira de Ciências Farmacêuticas. São Paulo, v. 42, n. 2, Jun. 2006. VEIGA Jr., V.F. et al. Plantas medicinais: cura segura?. Química Nova, v.28, n.3, p.519-528, 2005.

WICHTL, M. Herbal Drugs and Phytopharmaceuticals: a handbook for practice on a scientific basis. 3.ed. Stuttgart: Medpharm GmbH Scientific Publishers; 2004. 582p.

WILLEMS, M. et al. Anthranoid self-medication causing rapid development of melanosis coli. Netherlands Journal of Medicine, v.60, n.1, p.22-24, 2003.

YUNES, R.A. et al. Fármacos e fitoterápicos: a necessidade do desenvolvimento da indústria de fitoterápicos e fitofármacos no Brasil. Química Nova, v.24, n.1, p.147-152, 2001. 